EMPOWER : Jurnal Pengembangan Masyarakat Islam

Vol. 4, No. 2, Desember 2019, hlm. 299-321

e-ISSN : 2580 - 0973, p-ISSN : 2580-085X

Tersedia Online di : http://syekhnurjati.ac.id/jurnal/index.php/empower

Email : empower@syekhnurjati.ac.id

\title{
Islam Agama Penguasa Dunia
}

\author{
Dr. Yayat Suryatna, M.Ag \\ IAIN Syekh Nurjati Cirebon
}

Email: Suryatnayayat@yahoo.co.id

\begin{abstract}
Abstrak
Secara konseptual maupun empiris Islam telah terbukti mampu membangun peradaban dunia yang luar biasa. Ketika bangsa Arab Pra Islam yang bukan apa-apa, dalam waktu relatif singkat menjadi bangsa yang ditakuti, dihormati, disegani dan menjadi penguasa di muka bumi, itu semua diperoleh berkat ajaran islam. Namun sayangnya, capaian luar biasa yang telah diraih umat Islam Era Klasik (650-1250 M) dan Era Pertengahan (1250-1800 M) kini tinggal kenangan. Realitas menunjukkan bahwa kondisi mayoritas umat Islam di dunia saat ini berada jauh di belakang umat-umat yang lain di berbagai sendi kehidupan. Secara ekonomi, kekuatan umat Islam kini tergolong marjinal. Meskipun banyak negara Muslim diberkahi dengan kekayaan sumber daya alam (natural resources) yang melimpah, namun struktur perekonomian mereka pada dasarnya rapuh dan tergantung pada kekuatan asing. Disebagian besar negara-negara Muslim, kemiskinan dan keterbelakangan juga masih menjadi fenomena yang akut. Berdasarkan realitas empirik umat Islam saat ini dikontraskan dengan kondisi umat Islam sebelumnya yang sangat kontradiktif tersebut, maka perlu dicari penyebab substantif dari keterpurukan umat Islam itu. Menurut Bambang Triatmojo maju tidaknya suatu bangsa ditentukan oleh lima aspek yang harus menjadi fokus utama garapan umat Islam, yakni memiliki pemimpin yang berintegritas tinggi (siddiq), beraccountabilitas tak diragukan (amanah), berkapabilitas tinggi (fathanah) dan komunikatif (tabligh).
\end{abstract}

\section{Kata Kunci: Islam, Membangun, Peradaban Dunia}

\begin{abstract}
Conceptually and empirically Islam has proven capable of building extraordinary world civilizations. When the Pre-Islamic Arabs who were nothing, in a relatively short time became a nation that was feared, respected, respected and became the ruler of the earth, it was all obtained thanks to the teachings of Islam. But unfortunately, the extraordinary achievements that have been achieved by Muslims
\end{abstract}


in the Classical Era (650-1250 AD) and the Middle Era (1250-1800 AD) are now only memories. Reality shows that the condition of the majority of Muslims in the world today is far behind other people in various aspects of life. Economically, the strength of Muslims is now classified as marginal. Although many Muslim countries are endowed with abundant natural resources, their economic structure is inherently fragile and dependent on foreign powers. In most Muslim countries, poverty and underdevelopment are also acute phenomena. Based on the empirical reality of Muslims today is contrasted with the conditions of the previous Muslim community which is very contradictory, it is necessary to look for substantive causes of the deterioration of Muslims. According to Bambang Triatmojo whether or not a nation is determined by five aspects must be the main focus of the work of the Muslims, namely to have leaders with high integrity (siddiq), to account for the undoubted (mandate), high capability (fathanah) and communicative (tabligh).

Keyword: Islam, Building, World Civilization

\section{A. Pendahuluan}

\section{Latar Belakang}

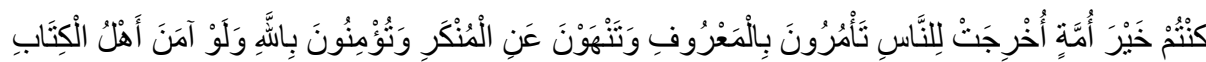

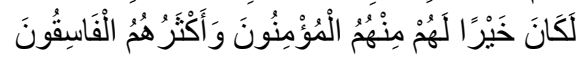

"Kamu (umat Islam) adalah umat terbaik yang dilahirkan untuk manusia, (karena kamu) menyuruh (berbuat) yang makruf, dan mencegah dari yang mungkar, dan beriman kepada Allah" (QS. 3: 110). Ayat ini mengandung arti bahwa umat Islam terlahir ke dunia adalah untuk menjadi umat terunggul dan terdepan dalam segala bidang kehidupan, baik bidang politik, kualitas sumber daya manusia, kebersihan dan kesehatan, penguasaan ilmu pengetahuan dan teknologi, serta di bidang kesejahteraan ekonominya.

Ayat ini mengandung arti bahwa umat Islam terlahir ke dunia adalah untuk menjadi umat terunggul dan terdepan dalam segala bidang kehidupan, baik bidang politik, kualitas sumber daya manusia, kebersihan dan kesehatan, penguasaan ilmu pengetahuan dan teknologi, serta di bidang kesejahteraan ekonomi dan sebagainya.

Al-Qur'an Surat 24 An-Nur ayat 56 lebih jauh mempertegas lagi dengan menyatakan :

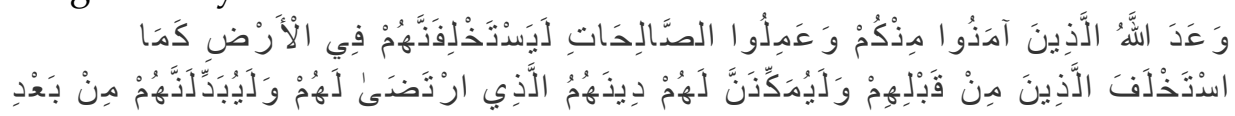




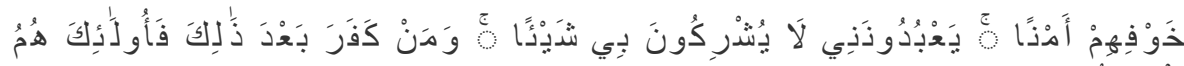



Allah telah menjanjikan kepada orang-orang di antaramu yang beriman dan mengerjakan kebajikan, bahwa Dia sungguh akan menjadikan mereka berkuasa di muka bumi sebagaimana Dia telah menjadikan orang-orang sebelum mereka berkuasa, dan sungguh Dia akan meneguhkan bagi mereka dengan agama yang telah Dia ridhoi. Dan Dia benar-benar mengubah (keadaan) mereka, setelah berada dalam ketakutan menjadi aman sentosa. Mereka tetap beribadah kepada-Ku dengan tidak mempersekutukan-Ku dengan sesuatupun. Tetapi barang siapa (tetap) kafir setelah (janji) itu, maka mereka itulah orang-orang yang Fasik¹.

Rasulullah terkait dengan hal ini bersabda : "Sesungguhnya Allah merengkuhkan bumi untukku, lalu aku lihat belahan timur dan baratnya. Sesungguhnya kekuasaan umatku akan mencapai belahan bumi yang direngkuhkan untukku dan aku diberi dua kekayaan:merah (emas) dan putih (perak). Aku juga memohon pada Tuhanku untuk umatku agar Dia tidak membinasakannya (melalui) paceklik massal dan tidak memberikan kekuasaan pada musuh untuk mengalahkan atas mereka selain dari kalangan mereka sendiri hingga mereka (musuhmusuh di luar umat tersebut) menumpas populasi mereka. Tuhanku berfirman,hai Muhammad, sesungguhnya jika aku sudah memutuskan sesuatu,maka tidak ada kekuatan apapun yang mampu menolaknya. Aku beri kamu demi umatmu untuk tidak membinasakan mereka dengan bencana paceklik massal dan tidak akan Aku beri kuasa pada musuh untuk mengalahkan mereka dan menumpas populasi mereka, selain dari kalangan mereka sendiri, meskipun mereka dikepung dari berbagai penjuru, sampai sebagian dari mereka membinasakan sebagian yang lain, dan saling menawan satu sama lain". (HR. Muslim,Abu Daud, At Tirmidzi, Al-Baehaqi,Ibnu Hibban dan AlHakim $)^{2}$

1 Samir Abdul Halim et all.Ensiklopedia Sains Islami,Jilid 7, Tangerang, Kamil Pustaka, Cet.1,2015,hal.126-127.

2 Samir Abdul Halim et all,ibid,. 
Berdasarkan ayat Al-Qur'an dan Hadits Nabi di atas, umat Islam terlahir ke dunia ini bukan hanya menjadi umat terbaik (QS. 3: 110), tetapi bahkan menjadi umat penguasa di muka bumi (QS.24 An-Nur/56 dan Hadits Rasulullah). Itulah pernyataan Al-Qur'an yang diyakini umat Islam tidak pernah bohong, dan memang realitas sejarah membuktikan bahwa umat Islam pernah menjadi umat terbaik dan pernah menjadi umat penguasa dunia.

\section{Kajian Literatur dan Teori}

\section{a. Fakta Historis Kejayaan Umat Islam}

Fakta sejarah menunjukkan bahwa hanya berselang enam dekade (enam puluh tahun) setelah Islam pertama kali didakwahkan oleh Rasulullah SAW, bangsa Arab yang semula tidak diperhitungkan dalam kancah geopolitik dan geoekonomi, tampil menjadi kekuatan baru di pentas dunia. Dalam waktu yang amat singkat, mereka berhasil meruntuhkan hegemoni Persia dan Romawi, dua negara adidaya yang ada saat itu, dan melebarkan jangkauan teritorinya hingga mencapai dua pertiga belahan dunia. Bahkan, Napoleon Bonaparte, panglima militer Prancis yang ternama, pun mengakui kehebatan kaum Muslimin dan menunjukkan kekagumannya kepada sosok Nabi Muhammad, ‘Umar bin Khattab dan para jenderal Muslim lainnya’

Baik imperium Bizantium maupun Sassaniyyah telah dibuat lemah oleh berbagai penyakit menular dan peperangan yang panjang. Direnggutnya kembali Syuriah oleh Bizantium tercapai setelah kekalahan Sassaniyyah pada $629 \mathrm{M}$, dan pencapaian itu pun masih bersifat permukaan. Bangsa Arab yang menaklukan kedua imperium tersebut bukanlah gerombolan suku, melainkan kekuatan terorganisasi, sebagian anggotanya telah memiliki kecakapan dan pengalaman militer ketika mengabdi pada imperium atau ketika mereka beperang setelah wafatnya Nabi. Penggunaan unta memberi mereka keuntungan di medan-medan peperangan yang mencakup

3 Mohammad Arif Budiman, Revitalisasi Kekuatan Ekonomi Umat, Kompasiana, http://www.kompasiana.com/moch_arif_budiman/revitalisasi-kekuatan-ekonomiumat_552ac2056ea834ae4d552d0f 
wilayah yang luas. Impian terhadap tanah dan kekayaan menciptakan koalisi kepentingan di kalangan mereka. Dan yang utama, gairah keyakinan keislaman memberi mereka suatu jenis kekuatan yang lain ${ }^{4}$.

Demikianlah, Agama Islam, seperti Agama Kristen, adalah agama dunia dengan misi universal. Tetapi, ia berbeda dengan Agama Kristen karena kesatuan dan totalitas pandangan Islam pada realitas. Tuhan adalah esa (Tauhid), semua ciptaan-Nya mempunyai kesatuan yang melatari dan tunduk pada perintah-Nya. Tuhan adalah penguasa yang berdaulat, dan manusia sebagai khalifah-Nya, harus melaksanakan perintah-Nya di bumi. Karena itu, agama tidak terpisah, malahan utuh bagi setiap aspek kehidupan: shalat, puasa, politik, hukum dan masyarakat. Keyakinan ini tercermin tidak hanya dalam doktrin tauhid, tapi juga sangat konkrit baik dalam masyarakat maupun dalam hukum (syari'at) Kepemimpinan sosial dan agama dilaksanakan Nabi Muhammad sebagai rasul Allah di muka Bumi5.

Peran Islam dalam perluasan wilayah kekuasaan sangat besar seperti dikemukakan Albert Hourani dalam bukunya A History of The Arab Peoples yang diterjemahkan ke dalam bahasa Indonesia oleh Irfan Abu Bakar menjadi "Sejarah Bangsa-Bangsa Muslim" ia menyatakan :

Keyakinan akan alam semesta yang Ilahiyyah dan misi komunitas telah dikukuhkan dan dikuatkan oleh keberhasilan dan kekuasaannya di sepanjang jalan sejarah Islam. Dalam masa seratus tahun sejak Nabi wafat, komunitas Islam lewat berbagai ekspansi dan penaklukan, telah berubah menjadi suatu kemaharajaan yang tak terpermanai luasnya di dunia ini. Hanya dalam sekejap, dunia Islam telah membentang dari Arab ke belahan barat di Afrika Utara

4 Albert Hourani, A History of The Arab Peoples yang diterjemahkan ke dalam bahasa Indonesia oleh Irfan Abu Bakar menjadi "Sejarab Bangsa-Bangsa Muslim", Bandung, Mizaan, 2004, hal.75.

5 John L.Esposito (ed.), Voices of Resurgent Islam, yang diterjemahkan oleh Bakri Siregar ke dalam bahasa Indonesia dengan judul Dinamika Kebangunan Islam, opcit, hal.2-3. 
dan Spanyol, dan ke belahan timur sampai di Indonesia. Di samping membangun lembaga-lembaga politik, sosial dan hukum, Islam juga melahirkan suatu peradaban yang amat tinggi. Filsafat, matematika, geometri, optik, ilmu alam dan ilmu sastra adalah sumbangan para sarjana muslim. Sementara Agama Kristen (Barat), tengah sibuk sedang menempuh abad-abadnya yang gulita, peradaban Islam semarak dan sedang mencapai puncaknya: dunia muslim telah menjadi ajang pusat-pusat utama ilmu pengetahuan dan kebudayaan'6.

Bukan hanya secara militer, umat Islam pada zaman kegemilangannya adalah pemegang supremasi di seluruh sektor kehidupan dan peradaban umat manusia. Mereka unggul secara ekonomi, politik, budaya, sains, teknologi, filsafat, seni, dan arsitektur. Pada zamannya, daulah Islamiyah berperan laksana mercusuar di tengah kegelapan dunia, menjadi referensi dan benchmark bagi umat-umat agama yang lain.

\section{b. Realitas Empirik Umat Islam Saat Ini}

Namun sayangnya, supremasi itu kini telah terlepas dari umat Islam. Capaian luar biasa yang telah diraih umat Islam Era Klasik (650-1250 M) dan Era Pertengahan (1250-1800 M) kini tinggal kenangan. Hampir di seluruh muka bumi ini, saat ini umat Islam menjadi umat marjinal, umat pinggiran yang tersisih dari gemerlapnya peradaban. Realitas menunjukkan bahwa kondisi mayoritas umat Islam di dunia saat ini berada jauh di belakang umat-umat yang lain di berbagai sendi kehidupan. Secara ekonomi, kekuatan umat Islam kini tergolong marjinal. Meskipun banyak negara Muslim diberkahi dengan kekayaan sumber daya alam (natural resources) yang melimpah, namun struktur perekonomian mereka pada dasarnya rapuh dan tergantung pada kekuatan asing.

Disebagian besar negara-negara Muslim, kemiskinan dan keterbelakangan juga masih menjadi fenomena yang akut. Negaranegara Muslim yang berhimpun dalam Organization of Islamic 
Cooperation/ OIC (sebelum tahun 2011 bernama Organization of Islamic Conference) yang merupakan asosiasi lintas negara terbesar kedua setelah PBB dengan anggota sebanyak 57 negara. Namun secara akumulasi, negara-negara OIC hanya mampu memproduksi $7,2 \%$ saja dari total GDP dunia. Dengan penduduk mencapai 22,5\% dari total populasi dunia, mereka hanya berkontribusi $9 \%$ dari total nilai perdagangan dunia (world trade) dan $12 \%$ dari nilai perdagangan di antara negara anggotanya (intra-trade). Sebagai komparasi, negaranegara Uni Eropa yang berpenduduk hanya 8\% dari total penduduk bumi, mampu membukukan 35\% dalam perdagangan dunia dan $60 \%$ dalam perdagangan di antara sesama anggotanya (Hakim, et al, 2012; Hasan, 2009).

Data di atas menunjukkan bahwa kekuatan ekonomi umat Islam kontemporer masih sangat marjinal, kurang produktif, tidak kompetitif, dan tidak memiliki kerjasama dan networking yang baik di antara sesamanya maupun dengan negara-negara non-Muslim lainnya. Faktor Kejayaan Umat Ketika mendapat pertanyaan dari Syekh Bisyooni Umran, Imam di Kerajaan Sambas, Kalimantan Barat, tentang penyebab kemunduran umat Islam dan kejayaan bangsa-bangsa non-Muslim (limadza ta'akhkharal Muslimun wa limadza taqaddama ghairuhum), Syakib Arslan, cendekiawan Muslim yang hidup sezaman dengan Rasyid Ridho, menjelaskan bahwa kondisi internal umat Islam saat ini sudah jauh berbeda dibandingkan generasi pendahulunya. Itu karena mereka telah meninggalkan atau mengabaikan faktor penyebab kejayaan para pendahulunya tersebut, yaitu bekerja dan berjuang dengan misi tunggal untuk meninggikan agama Allah, bukan untuk kepentingan duniawi semata.

Apakah pantas, lanjut Arslan, jika umat Islam saat ini berharap meraih kejayaan yang sama dengan hanya mengandalkan lima persen kadar kerja mereka sementara para pendahulunya telah mengorbankan seratus persen kerja mereka untuk kejayaan agama ini? Tentu saja Allah tidak akan memberikan kejayaan dan kemenangan begitu saja. Dia menuntut dan menyaratkan kesungguhan dan pengorbanan yang sebanding dari umat Islam 
seperti ditegaskan dalam ayat, "Sesungguhnya Allah membeli dari orang-orang mukmin, baik diri maupun harta mereka, dengan memberikan surga untuk mereka." (QS. 9: 111). Pepatah juga mengatakan, "barang siapa menanam, ia akan memanen." Jadi, sesungguhnya umat Islam-lah yang telah berubah sehingga Allah pun mengubah nasib mereka. Inilah pemahaman yang sebenarnya dari ayat, "Sesungguhnya Allah tidak akan mengubah keadaan suatu kaum sebelum mereka mengubah keadaan diri mereka sendiri" (QS. 13: 11). Allah berjanji bahwa sepanjang umat Islam beriman dan bertaqwa (dengan sebenar-benarnya), maka Dia akan menurunkan keberkahan dari langit dan bumi, namun sebaliknya jika mereka mendustakaan ayat-ayat-Nya, maka siksaan dan kehinaan pun akan ditimpakan kepada mereka (QS. 7: 96). Selain itu, kecintaan kepada dunia dan takut mati (hubbuddunya wa karahiyatul mati), juga menjadi penyakit umat yang harus disembuhkan karena hal itu menjauhkan dari rahmat Allah.

Ketika mereka cinta kepada dunia, maka Allah justru tidak akan memberikan dunia itu kepada mereka. Sebaliknya, jika dunia bukan lagi menjadi tujuan mereka, maka Allah akan meletakkannya di dalam genggaman tangan dan di bawah tapak kaki mereka. Pilar Kekuatan Ekonomi Umat Islam perlu dibangun secara terstruktur dengan merevitalisasi empat prinsip dasar yang meliputi: (1) prinsip Tauhid; (2) prinsip profesionalisme; (3) prinsip kerjasama; dan (4) prinsip independensi atau otonomi. Prinsip tauhid yang berintikan penegasan atas keesaan Allah merupakan intisari dari aqidah Islamiyah dan berfungsi sebagai ikatan paling kokoh yang menyatukan umat Islam seluruh dunia. Madzhab dan aliran bisa bermacam-macam, namun pengakuan atas tauhidullah tidak mungkin berbeda. Ini menjadi modal utama yang bisa merekatkan umat, menyingkirkan kepentingan-kepentingan selainnya, dan menempatkan semua kelompok, organisasi, negara dan bangsa Muslim dalam posisi dan kedudukan yang sederajat menuju terwujudnya kekuatan ekonomi umat. 
Dengan aqidah yang benar, umat Islam memiliki kekuatan pendorong (driving force) dan penopang (back up) yang amat kuat sehingga mereka selalu optimis menghadapi tantangan dan tribulasi ekonomi yang berat. Di samping itu, prinsip tauhidullah ini akan menjadikan seluruh aktivitas ekonomi bernilai ibadah, bernuansa jihad dan penuh keberkahan. Prinsip Profesionalisme dalam perspektif ekonomi dan bisnis, profesionalisme merupakan kunci utama kesuksesan yang berkelanjutan. Jangan pernah membayangkan memiliki kekuatan ekonomi umat tanpa diiringi dengan kesungguhan (totalitas), keahlian, tata kelola yang baik (good governance), dan pelayanan prima (service excellence). Profesionalisme meniscayakan pengerahan segenap sumber daya untuk menghasilkan hasil kerja terbaik sebagaimana ditegaskan dalam Hadits Nabi, "Sesungguhnya Allah mencintai hamba yang apabila melakukan suatu pekerjaan maka dia melaksanakannya dengan cara yang terbaik (profesional)."

Prinsip ini juga menuntut umat Islam untuk belajar, membenahi diri, dan berinovasi secara terus menerus. Kisah Nabi Yusuf AS mengajarkan kepada kita tentang pentingnya sikap profesionalisme ini (QS. 12: 55). Selain itu, profesionalisme juga terkait erat dengan kemampuan mengelola waktu secara efektif dan efisien. Prinsip Kerjasama (Ta'awun) Islam memerintahkan umatnya untuk membangun kebersamaan (berjamaah) dan kerjasama dalam melaksanakan kerja-kerja kebaikan dan taqwa (QS. 5: 2) dalam satu barisan yang rapi dan teratur (bunyan marshush) (QS. 61: 4).

Dunia ekonomi tentu tidak bisa dilepaskan dari prinsip kerjasama ini karena pada hakikatnya tidak ada unit ekonomi sekecil apapun yang mampu memenuhi kebutuhannya sendirian, namun yang perlu lebih diprioritaskan adalah membangun kerjasama di antara sesama umat Islam atau sesama negara Islam. Urgensi kerjasama ekonomi ini telah menjadi pemahaman bersama masyarakat dunia sebagaimana tercermin dari terbentuknya Uni Eropa yang meleburkan perekonomian dan mata uang mereka 
dalam satu zona ekonomi bersama. Prinsip koperasi juga merupakan pengejawantahan dari sikap kerjasama ini.

Dalam skala internasional, umat Islam sudah memiliki OIC. Demikian pula di tanah air, terdapat berbagai aliansi bisnis umat seperti HIPMI, Asbisindo, BMT Center, Puskopontren, dan lain-lain. Semua organisasi umat ini perlu lebih meningkatkan lagi kerjasama dan jaringan bisnis di antara sesama anggotanya agar menghasilkan sinergi dan akselerasi pertumbuhan yang saling menguntungkan. Prinsip Independensi atau Otonomi Sistem ekonomi umat Islam pada dasarnya diarahkan menuju konsep swasembada dalam arti kemampuan memenuhi kebutuhannya sendiri (self-sufficiency) tanpa tergantung pada kekuatan eksternal. Sayangnya, dalam hal ini kita masih teramat lemah. Jangankan untuk memenuhi kebutuhan duniawi, untuk kebutuhan ibadah ritual saja kita masih belum bisa mandiri sepenuhnya.

Misalnya, untuk menunaikan ibadah haji kita terpaksa menggunakan pesawat yang diproduksi umat lain, bahkan untuk souvenir atau oleh-oleh jamaah haji pun banyak yang justru diproduksi oleh umat lain. Prinsip independensi juga menuntut komitmen pada produk lokal karya umat Islam sendiri, tentu diiringi dengan peningkatan kualitasnya dari waktu ke waktu. Kita juga perlu menghentikan ketergantungan kepada lembaga donor asing dengan cara meningkatkan penghimpunan dana umat dan mendukung operasionalisasi lembaga-lembaga keuangan syari'ah. Dengan kemandirian atau otonomi ini, maka umat Islam bisa tegak dengan penuh kewibawaan dan tidak dapat diintervensi oleh umatumat yang lain.

Bagi umat Islam, Allah-lah satu-satunya tempat bergantung dan meminta pertolongan. Catatan Penutup Kondisi ekonomi umat Islam yang secara umum terbelakang tidak akan berubah apabila umat Islam sendiri tidak berusaha mengubahnya. Diperlukan kesamaan arah dan tujuan kemana ekonomi umat ini akan dibawa. Sepanjang umat Islam tidak mau bersatu dan lebih senang berjalan sendirisendiri, maka selamanya keterpurukan ekonomi akan membekap 
umat ini dan satu demi satu urusan ekonomi umat akan berpindah ke tangan umat-umat yang lain. Umat Islam perlu merevitalisasi dan mengaktualisasikan prinsip tauhid, profesionalisme, kerjasama, dan otonomi dalam pengelolaan ekonomi di semua tingkatan dari skala lokal, nasional, regional, hingga global menuju terciptanya kejayaan Islam dan kaum Muslimin (li'izzatil Islam wal Muslimin).

Prinsip-prinsip inilah yang dulu telah mengantarkan umat Islam masa silam meraih supremasi dunia. Sudah tiba saatnya bagi kita untuk menghadirkan kejayaan tersebut di masa kini. Sehingga, pada suatu saat nanti pertanyaan menarik yang akan muncul, di benak umat-umat agama lain, adalah limadza taqaddamal Muslimun? (Mengapa umat Islam bisa maju ${ }^{7}$ Michael H. Hart dalam buku aslinya berjudul The 100, a Ranking of The Most Influential Persons in History yang diterjemahkan ke dalam bahasa Indonesia "Seratus Tokoh Paling Berpengaruh Dalam Sejarah" menempatkan Nabi Muhammad sebagai tokoh paling berpengaruh dalam sejarah di urutan No.1. Alasan dia menempatkannya di urutan No. 1 pun sangat masuk akal yakni dialah Nabi Muhammad satu-satunya manusia dalam sejarah yang berhasil meraih sukses-sukses luar biasa baik ditilik dari ukuran agama maupun ruang lingkup duniawi ${ }^{8}$. Tolak ukur yang digunakan dalam penentuan tokoh paling berpengaruh dalam sejarah tersebut adalah seberapa besar tokoh tersebut mempengaruhi jalannya sejarah tak peduli ia itu baik, buruk bengis atau jahannam.

Fakta tersebut menunjukkan bahwa Nabinya umat Islam adalah manusia luar biasa yang memiliki pengaruh luar biasa pula bagi dunia. Pengakuan tersebut tidak aneh kalau datang dari seorang muslim. Tapi pengakuan ini justru datang dari seorang non muslim yang objektif dalam menilai seseorang. Persoalan yang muncul saat ini adalah realitas empirik yang dialami umat Islam saat ini. Nabinya

7 Ibid hal.2.

8 Michael H. Hart, Seratus Tokob Paling Berpengarub Dalam Sejarah, (Jakarta: Dunia Pustaka Jaya, 1989 , hal.27. 
luar biasa hebat, tapi umatnya justru terpuruk dalam segala aspek kehidupan.

Kemajuan kolonialisme telah menyudutkan sejarah dan identitas Islam pada titik kritis. Sepanjang abad kesembilan belas agama Kristen mendesak Islam dari berbagai sudut baik dari sudut militer, ekonomi, maupun politik. Dengan begitu, setiap keberartian sejarah Islam sudah ditantang. Apa yang sebenarnya tejadi dalam Islam? Mengapa nasib kaum muslimin terbalik begitu drastis? Kehancuran tatanan politik Islam tradisional dan perlawanan menangkal campur tangan kolonialis Eropa beserta pemerintahannya memang telah mendatangkan krisis identitas, tapi sebaliknya, ia juga melahirkan gaya politik baru bagi kaum muslimin abad dua puluh yang modern. Di bawah pengaruh Barat dan pemerintahan kolonial, modernisasi telah terjadi di mana-mana. Secara kasar dapat dikatakan bahwa beberapa Negara muslim telah mengikuti jalan Barat dan sekulerisasi begitu mereka menerima pola-pola politik, hukum, dan pendidikan dari sana. Di sebagian besar dunia Islam, kecenderungan pemisahan agama dari Negara kian dapat dikenali. Masa jaya kekhilafahan dan sultan telah lenyap, hukum Islam sebagian telah lenyap diganti dengan aturan-aturan hukum Barat. Dan modernisasi sekuler, apakah itu politik, ekonomi, atau pendidikan kian dibangun di bawah atap pengawasan kolonial ${ }^{9}$.

Al-Amier Syakib Arsalan, dalam bukunya Limadza Taakhkhorol Muslimuuna Walimadza Taqoddama Ghoiruhum, yang diterjemahkan ke dalam bahasa Indonesia menjadi" Mengapa kaum muslimin mundur dan Mengapa Kaum Selain mereka maju? mengemukakan bahwa kemunduran dan kelemahan yang ditanggung oleh umat Islam itu adalah suatu peristiwa yang umum, yang rata bagi mereka baik di Timur maupun di barat tak hanya terjadi di Indonesia dan Malaya

9 John L.Esposito (ed.), Voices of Resurgent Islam, yang diterjemahkan oleh Bakri Siregar ke dalam bahasa Indonesia dengan judul Dinamika Kebangunan Islam, Jakarta: Rajawali, 1987, hal.4-5. 
saja melainkan meliputi seluruh umat Islam di mana pun mereka berada $^{10}$.

Menurut Bassam Tibi, seorang pemikir muslim Jerman asal Syria dalam bukunya, Crisis in Muslim Civilization, yang dikutip Dawam Raharjo ${ }^{11}$ menyatakan bahwa, “Dunia Islam secara keseluruhan dewasa ini masih berada dalam kultur pra-industri. Dalam keadaan demikian, mustahil bagi Dunia Islam untuk bersaing dengan Barat yang telah jauh berada dalam kultur industri modern".

Lebih jauh Dawam menerangkan bahwa walaupun jargon kebangkitan Islam telah dicetuskan pada abad ke-14 Hijriyah, hingga kini hanya menghasilkan seorang saja peraih Hadiah Nobel di bidang sains, yakni Abdussalam. Itu pun berasal dari aliran Ahmadiyah yang dianggap aliran sesat, bahkan tidak diakui sebagai bagian umat Islam, oleh lembaga-lembaga resmi umat Islam. Sementara dari aliran mayoritas (Suni dan Syi'ah), belum tampak seorang saintis pun yang menonjol berkaliber dunia semisal Abdus Salam.

Di antara negara-negara Muslim di dunia, belum satu pun yang dapat dikategorikan ke dalam negara Industri. Paling banter, negaranegara muslim disebut sebagai negara sedang membangun (develoving countries). Dua saja dari negara-negara itu yang tergolong berpendapatan tinggi (high income country), yakni Saudi Arabia dan Uni Emirat Arab. Itu pun karena kekayaan minyak dan gas bumi anugrah Tuhan yang dikembangkan oleh negara-negara industri maju, terutama Amerika Serikat (AS).

Meskipun demikian, kedua negara Arab itu tidak bisa disebut negara industri dan negara maju. Sementara kebanyakan negaranegara Muslim lainnya hingga kini masih bergelut dengan kemiskinan massal dan tingkat pendidikan rendah. Artinya,

10 Al-Amier Syakib Arsalan,dalam bukunya Limadza Taakhkhorol Muslimulna Walimadza Taqoddama Ghoiruhum, yang diterjemahkan ke dalam bahasa Indonesia menjadi" Mengapa Kaum Muslimin Mundur dan Mengapa Kaum Selain Mereka Maju, Jakarta, Bulan Bintang, 1967 , hal.15.

11 M. DawamRahardjo, Kritik Nalar Islamisme dan Kebangkitan Islam, Jakarta, Freedom Institute, 2012, hal. 3-4. 
mayoritas dari negara-negara Muslim masih diliputi oleh kebodohan dan kemiskinan, sehingga masih berada di buritan peradaban dunia.

Padahal, negara-negara non-Barat yang berperadaban Timur, setidaknya beberapa di antaranya, sudah ada yang memasuki tahap negara industri maju, seperti Jepang dan Singapura. Sementara yang lainnya, paling tidak masuk ke dalam kategori negara industri baru (newly industrializing countries), seperti Korea selatan,Taiwan dan Hongkong yang segera akan masuk ke era industrial maju. Terakhir Cina dan India, telah disebut-sebut sebagai raksasa ekonomi dunia, menandingi, bahkan mungkin mengungguli, AS dan Eropa. Di negara-negara itu, pendidikan dan ilmu pengetahuan telah berkembang pesat. Negara-negara itu telah mampu mengembangkan teknologi tinggi. India memang masih dikenal sebagai negara miskin. Tapi di lain pihak, India telah mengembangkan sistem pendidikan yang unggul. Seperti halnya Cina, India juga telah mengembangkan pusat teknologi IT dengan produk kelas dunia yang diekspor ke negara-negara industri maju. India juga telah melahirkan beberapa peraih Hadiah Nobel yang di antaranya adalah ekonom Amartya Sen. Di negara itu telah pula lahir lembaga-lembaga pendidikan menengah dan perguruan tinggi seperti politeknik dan lembaga pendidikan manajemen kelas dunia. Sementara tetangganya, Negara Islam Pakistan, masih berada dalam kemiskinan dan kediktatoran militer yang menginjak-nginjak hakhak asasi manusia (HAM).

Potret buram Dunia Islam juga dideskripsikan oleh Nurcholish Madjid, ia mengatakan, dewasa ini Dunia Islam merupakan kawasan bumi yang terbelakang di antara penganut agama-agama besar di dunia. Tidak ada satu pun penganut agama besar di muka bumi ini yang paling rendah ilmu pengetahuan dan teknologinya dari pada Islam. Dengan kata lain di antara semua penganut agama besar di muka bumi ini, penganut Islamlah yang paling rendah dan paling lemah sains dan teknologinya. ${ }^{12}$ 
Keterbelakangan umat Islam sesungguhnya bukan hanya di bidang sains dan teknologi, tetapi juga dalam berbagai segi kehidupan lainnya, seperti dalam bidang politik dan ekonomi. Dalam bidang ekonomi, Maxime Rodinson menyatakan bahwa, sebagian besar negara-negara yang sedang berkembang atau negaranegara miskin adalah negara-negara Islam. ${ }^{13}$

Rendahnya kondisi perekonomian umat Islam tersebut dapat dilihat misalnya, dalam World Development Report 1997 yang dikeluarkan oleh Bank Dunia. Isi laporan Bank Dunia itu antara lain menyatakan, selama tahun 1985-1995, pendapatan rata-rata perkapita pertahun (GNP) penduduk dunia adalah US.\$ 4.880, sedangkan pendapatan rata-rata perkapita pertahun negara-negara Islam atau negara-negara berpenduduk mayoritas muslim, rata-rata US \$ 1.050.14 Laporan tersebut menunjukkan bahwa, pendapatan rata-rata penduduk muslim, kurang dari $25 \%$ pendapatan rata-rata penduduk dunia.

\section{B. Pembahasan}

\section{Analisis Permasalahan Tentang Kemunduran Umat Islam}

Berdasarkan realitas empirik umat Islam saat ini dikontraskan dengan kondisi umat Islam sebelumnya yang sangat kontradiktif tersebut, maka perlu dicari penyebab substantif dari keterpurukan umat Islam itu. Sesungguhnya, berbagai upaya untuk mengejar kemajuan, telah banyak dilakukan oleh para pemimpin Islam seperti, Mustafa Kemal Attaturk di Turki melalui pendekatan sekulerismenya, bahkan Turki Uthmani dianggap pelopor sekulerisme di dunia Islam. Tetapi karena berbagai sebab yang sangat kompleks, Turki gagal, bahkan tertinggal jauh sekali oleh Jepang dan kini oleh Negara-negara industri maju di Asia Timur. ${ }^{15}$

13 Maxime Rodinson, Islam dan Kapitalisme, ter. Asep Hikmat (Bandung, Iqra, 1982), hal. 25.

14 Said Zainal Abidin, "Globalisasi dan Pembangunan Ekonomi Rakyat," dalam Pembangunan Ekonomi Nasional, ed. Dawam Raharjo (Jakarta: Kadermasa, 1997), hal.287-289.

15 Madjid, Kaki Langit, hal.22-23. 
Sebenarnya, kebangkitan Islam mengacu pada dua kata yaitu Tajdid dan Islah. Tajdid biasanya diterjemahkan sebagai "pembaharuan",dan "islah", sebagai perubahan. Pada hakekatnya, tradisi besar untuk memperbaharui dan mengubah ini menggambarkan upaya perseorangan dan bersama untuk mewujudkan Islam dengan jelas dan tegas, sesuai dengan wahyu Tuhan) sebagaimana termaktub dalam Al-Qur'an) dan kebiasaan-kebiasaan atau Sunnah Nabi Muhammad. Dalam keadaan yang berubah, dan dengan implikasi yang berbeda-beda, islah dan tajdid selalu mencakup seruan untuk kembali kepada asas-asas pokok Islam seperti dikemukakan dalam AlQur'an dan Sunnah Nabi. ${ }^{16}$

Pertanyaannya adalah, mengapa umat Islam itu sulit sekali dimajukan atau memajukan diri? Mengapa Restorasi Meiji di Jepang jauh lebih sukses dibanding westernisasi Turki oleh Mustafa Kemal Attaturk? Mengapa pula pembaharuan di Cina lebih sukses dibanding dengan pembaharuan dalam Islam yang dilakukan oleh Muhammad Abduh, Rasyid Ridha, Jamaluddin Al-Afghani di Mesir dan Mohammad Ali Jinnah di Pakistan, bahkan oleh Ahmad Dahlan dengan Muhammadiyahnya di Indonesia? Atau memang kebangkitan itu butuh waktu panjang? Berapa abad lagikah umat Islam harus mengalami keterpurukannya? Kesalahan macam apakah yang dilakukan umat Islam sehingga mengalami musibah berkepanjangan? Mungkin masih ribuan lagi pertanyaan bisa diajukan untuk menggugat kondisi pahit umat Islam saat ini, guna mendapatkan jawaban yang tepat bagi tumbuh kembalinya umat Islam menjadi penguasa dunia.

Tentu saja untuk menjawab pertanyaan-pertanyaan tersebut tidak bisa dijawab dengan mudah dan dengan analisis sederhana. Sebab penyebab ketertinggalan umat Islam dari umat lainnya tidak disebabkan oleh faktor yang tunggal tetapi disebabkan oleh faktor yang sangat kompleks. Setidaknya secara garis besar disebabkan oleh dua faktor yaitu faktor eksternal ( dari luar Islam) dan faktor internal (dari dalam umat Islam sendiri). Dari faktor eksternal misalnya, penjajahan Barat atas dunia Islam telah membuat umat Islam menjadi umat 
tertindas, tertinggal dan terbelakang dalam segala aspek kehidupan, baik politik, ekonomi, teknologi, maupun bidang sosial dan budaya. Bahkan walaupun secara fisik, umat Islam telah merdeka, tetapi secara politik dan ekonomi, sejatinya masih banyak negara muslim yang diintervensi oleh mantan penjajahnya.

Sedangkan penyebab dari dalam umat Islam sendiri cukup banyak, di antaranya faktor kurang kekompakan atau lemahnya persatuan sesama umat Islam dalam menyikapi berbagai persoalan yang menimpanya. Di samping itu, hal lain yang tidak kalah pentingnya adalah adanya polarisasi pemahaman Islam yang beraneka ragam yang diduga pula berkontribusi besar terhadap lambannya gerak umat Islam dalam mengejar ketertinggalan.

Pertama, adanya persepsi di sebagian umat Islam bahwa mencari harta kekayaan sebanyak-banyaknya, menguasai ilmu pengetahuan dan teknologi setinggi-tingginya, menjadi penguasa di muka bumi dan sebagainya yang terkait dengan kehidupan duniawi, seolah-olah itu bukan tugas penting seorang muslim, dan dianggap bukan ibadah.

Persepi Islam seperti ini lebih cenderung berorientasi pada akhirat semata, atau lebih mementingkan akhirat dari pada dunia, bukan membangun keseimbangan antara keduanya. Akibatnya, indikator keislaman seseorang diukur hanya, atau menitikberatkan pada pelaksanaan ibadah mahdoh (ritual) semata, misalnya diukur dari tingkat ketaatan shalatnya, puasanya, hajinya dan zakatnya, kurang mempertimbangkan aspek lain yang bersifat keduniawian.

Pemahaman Islam seperti ini akan berdampak pada kurang gigihnya mereka dalam memperjuangkan kehidupan duniawi. Etos kerja dan produktivitas kerja mereka diprediksi akan rendah. Dampak susulannya tentu saja pada aspek penguasaan duniawi yang rendah pula. Berkorelasi dengan anggapan di atas, maka ibadah-ibadah dalam Islam seperti puasa, zakat, haji dan shalat semuanya berorientasi ukhrowi, tidak, atau jarang sekali dikorelasikan dengan persoalanpersoalan kehidupan real umat manusia saat ini. Seperti pemberantasan kemiskinan, kebodohan, ketimpangan (gap) antara kaya-miskin dan lain-lain. Akibat dari persepsi tentang Islam tersebut, maka ghiroh atau 
semangat umat Islam untuk menjadi umat Terbaik, umat unggulan dalam segala kehidupan menjadi melemah. Dan ini dibuktikan dalam kehidupan Islam saat ini yang tertinggal jauh dari umat lain.

Kedua, adanya anggapan bahwa Islam sudah tidak cocok dengan perkembangan zaman saat ini, sehingga peran Islam hanya sebatas mengatur hubungan manusia dengan Tuhannya dalam bentuk ibadah mahdoh. Sedangkan kehidupan antar sesamanya Islam tidak diperkenankan ikut campur (sekuler).Pemahaman ini akan berdampak pada ditinggalkannya ajaran Islam dari kehidupan sehari-hari. Semangat hidup dalam keseharian dengan motivasi, ruh dan berpedoman pada ajaran Islam menjadi hilang. Bagaimana umat Islam bisa maju dengan pola pikir semacam ini, karena justru umat Islam era klasik dan pertengahan itu, maju karena Islam, bukan karena sekuler. Eksperimen sekulerisme Mustafa Kemal Attaturk di Turki gagal membawa Turki menjadi Negara maju. Sebenarnya, pemahaman sekuler ini ada kesamaan dengan pemahaman Islam akhirat oriented, yakni sama-sama meninggalkan Islam dari kancah kehidupan duniawi. Perbedaannya, Islam sekuler memisahkan Islam dari kehidupan duniawi dengan mengambil konsep luar Islam sebagai acuan. Sedangkan Islam akhirat oriented, mengambil Islam tetapi berorientasi ke kehidupan akhirat semata. Kehidupan dunia kurang diperhatikan. Akibat dari dua pemahaman tersebut melahirkan muslim yang jauh dari ajaran Islam (sekuler), dan muslim yang jauh dari kehidupan dunia (sufisme tertentu).

Ketiga, adanya persepsi bahwa kondisi keterpurukan umat Islam saat ini merupakan sesuatu yang memang seharusnya, karena dunia itu surga bagi kafir dan penjara bagi mukmin. Persepsi tentang Islam seperti ini, diprediksi dapat melemahkan semangat juang umat Islam dalam mengejar ketertinggalannya dari umat lain. Persepsi seperti ini membentuk alam bawah sadar umat Islam bahwa kehidupan di dunia yang serba kekurangan, ketinggalan, serba susah sebagai sesuatu yang memang seharusnya dilalui umat Islam. Padahal berkaca dari sejarah, umat Islam era Rasulullah, khulafaurrasyidin dan dinasti berikutnya, adalah umat Islam yang sejahtera baik secara ekonomi, politik, 
teknologi dan sebagainya, bahkan menjadi penguasa dunia. Menurut Bambang Triatmojo, 17 maju tidaknya suatu bangsa ditentukan oleh beberapa hal, di antaranya oleh hal-hal sebagai berikut :

\section{a. Peran Pemimpin}

Besarnya peran pemimpin terhadap kemajuan suatu bangsa dapat dilihat dari Bangsa Korea. Setelah merdeka dari penjajahan Jepang selama 35 tahun, yaitu pada tanggal 15 Agustus 1945, terjadi perang saudara yang mengakibatkan Korea pecah menjadi dua Negara yaitu Korea Utara dan Korea Selatan. Pemimpin Korea Utara yang diktator dan lebih memprioritaskan pada kemajuan militer telah membawa rakyatnya hidup terbelakang dan miskin. Sementara pemimpin Korea Selatan yang lebih mengedepankan pembangunan ekonomi telah menjadikan Negara ini sangat maju, kaya dan rakyatnya hidup lebih sejahtera. Meskipun mereka satu bangsa, satu tumpah darah, satu budaya, satu bahasa; namun kebijakan pemimpinnya telah menjadikan kondisi kedua Negara sangat jauh berbeda, seperti bumi dan langit. Korea Selatan menjadi Negara sangat maju, makmur, dan sejahtera; sementara Korea Utara termasuk Negara berkembang, miskin dan tidak aman.

Contoh di atas menunjukkan bahwa pengaruh dan kebijakan pimpinan suatu Negara sangat berpengaruh terhadap maju mundurnya suatu Negara, sejahtera tidaknya rakyatnya. Karena begitu besarnya pengaruh pimpinan suatu Negara maka proses pemilihan seorang kepala Negara dan kepala pemerintahan harus benar-benar serius, melalui seleksi yang ketat dan tidak dapat diperjualbelikan dengan harga sebesar apapun. Jika proses pemilihan dipenuhi dengan aroma pembelian suara, maka yang akan memenangkan kepemimpinan adalah para pemilik modal. Jika hal itu terjadi maka ketika seseorang terpilih jadi pemimpin yang pertama akan ia pikirkan bukan bagaimana memajukan dan menyejahterakan rakyat, tetapi bagaimana ia mengembalikan modal besar yang telah ia habiskan saat pemilihan.

17 Bambang Triatmojo, Menuju Kejayaan Umat Islam, Yogyakarta, Beta Offset,2015, hal.209. 


\section{b. Budaya Kerja dan Etos Kerja}

Budaya kerja keras dan etos kerja yang tinggi, rajin, jujur, pantang menyerah, hidup hemat, mandiri, inovatif, senang membaca, dan kerjasama adalah kunci kemajuan bangsa. Hal ini dapat dilihat dari kemajuan Bangsa Korea selatan yang mampu menyejajarkan diri dalam kemajuan teknologinya dengan Jepang. Jepang sendiri memperoleh kemajuan menyaingi Eropa Barat dan Amerika didorong oleh semangat kerja keras, disiplin tinggi, pantang menyerah, totalitas, loyalitas, semangat kerjasama, menjunjung tinggi tradisi, kode etik dan tata krama dalam kehidupan.

Saat ini Jepang menjadi Negara maju di bidang ekonomi dengan produk domestik bruto (PDB) terbesar ketiga setelah Amerika Serikat dan Cina, yaitu sebesar US\$ 5,87 triliun. Populasi Jepang sekitar 128 juta orang. PDB percapita sebesar US\$ 33.596 atau sekitar 410 juta/tahun yang berada pada peringkat 23 dunia. Indeks Pembangunan manusia (IPM) berada pada peringkat ke-10 dunia, yang menunjukkan standar hidup rakyat jepang yang tinggi dan termasuk Negara sangat maju. Nilai Indeks persepsi korupsi adalah 8 dan berada pada peringkat ke-14 dunia, yang menunjukkan Jepang relative bersih dari tindak korupsi. ${ }^{18}$ Bangsa Jepang telah berhasil bangkit dari kemiskinan dan ketertindasan menjadi bangsa yang maju dan kaya dalam waktu relatif singkat.

\section{c. Pendidikan}

Pendidikan merupakan modal dasar untuk kemajuan suatu bangsa. Pendidikan bisa meningkatkan kehidupan sosial dan ekonomi seseorang sehingga dapat membawanya pada kesejahteraan yang lebih baik, baik bagi dirinya maupun keluarganya. Pendidikan ibarat eskalator bangsa yang akan membawa perubahan terwujudnya suatu bangsa baru yang lebih maju, lebih makmur, lebih sejahtera dan lebih bermartabat

18 Bambang Triatmojo, Op.Cit, hal.225. 


\section{d. Pengembangan Iptek dan Industri}

Negara kaya, maju dan makmur adalah Negara yang menguasai ilmu pengetahuan dan teknologi. Dengan ilmu pengetahuan dan teknologi hidup menjadi lebih mudah dan nyaman. Kemajuan Iptek akan diikuti oleh kemajuan di bidang ekonomi, kedokteran, pertanian, budaya, dan bidang lainnya. Itu pula lah yang dialami umat Islam terutama di era kejayaanya yakni era Bani Abbasiyah. Amerik Serikat (AS) dengan kemajuan Ipteknya telah membawanya menjadi Negara adidaya. AS menjadi Negara dengan kekuatan ekonomi dan politik terbesar di dunia. Demikian pula Jepang, dengan kemajuan Ipteknya, mampu menjadi Negara maju, kaya, makmur dan bermartabat.

Eropa bisa maju juga karena mampu menguasai Iptek yang dimulai sejak zaman Renaisans abad 14-15 M. seperti Leonardo Davinci (1452-1519) dan Michel Angelo (1475-1564) di bidang seni, Johann Gutenberg (1400-1468) penemu mesin cetak, Nicolaus Copernicus (1478-1543), Galileo Galilei (1546-1642) Johannes Kepler (1571-1642) ketiganya di bidang astronomi.

Pada tahun-tahun berikutnya telah lahir ilmuwan-ilmuwan besar seperti Isaac Newton (1642-1727) fisikawan, James Watt (17361819) penemu mesin uap, Michael Faraday (1791-1867) fisikawan, James Clerk Maxwel (1831-1879) fisikawan, Orville Wright (18711948) dan Wilbur Wright (1867-1912) penemu pesawat terbang, Antoine Laurent Lavoisier (1743-1794) di bidang ilmu kimia, Guglielmo Marconi (1874-1937) penemu radio, Thomas Alfa Edison (1847-1931) penemu bola lampu pijar, Albert Einstein (1879-1955) fisikawan penemu teori relativitas, Karl Benz (1844-1929) penemu mobil bermesin bensin, Henry Ford (1863-1947) orang pertama yang memproduksi mobil secara massal dengan harga terjangkau, dan para ilmuwan lainnya. ${ }^{19}$

Dapat dipastikan pula bahwa, Negara-negara miskin adalah Negara yang tidak menguasai Iptek atau Negara yang kalah bersaing

19 Ibid, hal.246 
secara Iptek. Walaupun diwarisi sumber daya alam yang melimpah, tanpa menguasai Iptek, maka sulit bagi negara tersebut untuk menjadi Negara yang maju, makmur dan bermartabat.

\section{Kesimpulan}

Berdasarkan analisis Bambang tersebut, maka setidaknya lima aspek tadi harus menjadi fokus utama garapan umat Islam, yakni memiliki pemimpin yang berintegritas tinggi (siddiq), beraccountabilatas tak diragukan (amanah), berkapabilitas tinggi (fathanah) dan komunikatif (tabligh). Kemudian membangun budaya dan etos kerja yang tinggi, memajukan pendidikan, menguasai Ilmu Pengetahuan dan teknologi serta menguasai industri.

Di samping itu, yang tidak kalah pentingnya adalah perbaikan persepsi tentang Islam sendiri perlu dioptimalkan agar tidak terjadi perang batin di kalangan umat Islam. Perang batin dimaksud adalah di satu sisi ada sekelompok umat Islam yang ingin memajukan umat Islam dengan menguasai akses duniawi setinggi-tingginya dengan cara yang Islami, namun di sisi lain ada pula sekelompok umat Islam yang beranggapan seolah menguasai hal-hal duniawi itu tidak penting, yang diprioritaskan keakhiratan semata. Akibatnya umat menjadi bingung, konflik batin antara dua pilihan tadi. Jika ditambah lagi dengan konsep sekularisme, maka konflik batin umat Islam tentang agamanya menjadi semakin parah.

Padahal, baik secara konseptual, maupun secara bukti empiri Islam telah terbukti mampu membangun peradaban dunia yang luar biasa. Dalam waktu relative singkat, bangsa Arab Pra Islam yang bukan apa-apa, menjadi bangsa yang ditakuti, dihormati, disegani dan menjadi penguasa di muka bumi, itu semua diperoleh berkat ajaran islam. Dan memang Islam terlahir untuk menjadi umat terbaik yang menjadi penguasa dunia. Islam adalah konsep hidup yang menawarkan solusi terbaik yang rasional dan logis bagi perbaikan kehidupan umat manusia secara komprehensif. 


\section{DAFTAR PUSTAKA}

Samir Abdul Halim et all.Ensiklopedia Sains Islami.Jilid 7.Tangerang.Kamil Pustaka.Cet.1.2015.

Mohammad Arif Budiman. Revitalisasi Kekuatan Ekonomi Umat. Kompasiana.

http://www.kompasiana.com/moch arif budiman/revitalisasikekuatan-ekonomi-umat 552ac2056ea834ae4d552d0f

Albert Hourani. A History of The Arab Peoples yang diterjemahkan ke dalam bahasa Indonesia oleh Irfan Abu Bakar menjadi "Sejarah Bangsa-Bangsa Muslim". Bandung. Mizaan. 2004.

Michael H. Hart. Seratus Tokoh Paling Berpengaruh Dalam Sejarah. (Jakarta: Dunia Pustaka Jaya. 1989.

John L.Esposito (ed.). Voices of Resurgent Islam. yang diterjemahkan oleh Bakri Siregar ke dalam bahasa Indonesia dengan judul Dinamika Kebangunan Islam. Jakarta : Rajawali. 1987.

Al-Amier Syakib Arsalan.dalam bukunya Limadza Taakhkhorol Muslimuuna Walimadza Taqoddama Ghoiruhum. yang diterjemahkan ke dalam bahasa Indonesia menjadi" Mengapa Kaum Muslimin Mundur dan Mengapa Kaum Selain Mereka Maju. Jakarta. Bulan Bintang. 1967.

M. DawamRahardjo.Kritik Nalar Islamisme dan Kebangkitan Islam. Jakarta. Freedom Institute. 2012

Nurcholish Madjid. Kaki Langit Peradaban Islam.Jakarta Paramadina. 1997

Maxime Rodinson. Islam dan Kapitalisme. ter. Asep Hikmat. Bandung. Iqra. 1982

Said Zainal Abidin. "Globalisasi dan Pembangunan Ekonomi Rakyat." dalam Pembangunan Ekonomi Nasional. ed. Dawam Raharjo. Jakarta: Kadermasa. 1997.

Bambang Triatmojo. Menuju Kejayaan Umat Islam.Yogyakarta. Beta Offset.2015. 